\title{
Educação Médica: Também uma Questão de Gênero
}

\section{Medical Education as a Gender Issue}

Debora Diniz'

Há um número crescente de mulheres nas escolas de Medicina em todo o país. A feminizaçāo do ensino superior não é um fenômeno exclusivo das carreiras biomédicas, havendo, na verdade, poucos cursos em que as mulheres nāo estejam em maior número. Cursos como Filosofia ou Física, carreiras tradicionalmente masculinas, são solitárias exceçōes nesse processo de feminizaçaão do ensino superior. A expectativa é a de que a entrada massiva das mulheres nas carreiras médicas provoque também uma sensibilidade maior às perspectivas de gênero no ensino da Medicina. Mas por que o ensino médico deveria ser sensivel às perspectivas de gênero?

Os estudos de gênero foram formalmente instituidos em meados do século passado, como uma especialidade das ciências humanas que buscava compreender como os papéis do masculino e do feminino eram definidos e incorporados por diferentes grupos sociais. Foram os estudos de gênero que mostraram que nossas definiçōes de masculino e feminino eram antes resultado dos processos de socialização que mesmo uma ditadura da natureza. A expressão "nascemos machos e fêmeas e aprendemos a ser homens e mulheres", durante um longo tempo, foi a que melhor resumiu as ambiçōes analíticas dos estudos de gênero. Era preciso compreender como cada grupo social transformava a natureza em cultura, isto é, como se transformavam machos e fêmeas em homens e mulheres.

O reconhecimento de que os papéis e as definiçōes do masculino e do feminino eram resultados de escolhas e preferências socioculturais e não estritamente resoluçōes inabaláveis da natureza foi uma afirmação desconcertante para inúmeras áreas do conhecimento. O deslocamento do feminino e do masculino da esfera da natureza para a da cultura provocou mudanças estruturaäs em nossa compreensāo social. Desde entāo, da psicanálise à filosofia da ciência, da antropologia à Medicina, incorporou-se gradativamente a perspectiva de gênero no ensino e na pesquisa. Hoje, o reconhecimento de que a categoria gênero é uma lente que nos permite enxergar a realidade de maneira radicalmente diferente é comum a vários campos disciplinares.

Foram os estudos de gênero que sensibilizaram médicos e médicas para algumas sutilezas do processo saúde e doença. Questōes relacionadas à reproduçāo, à sexualidade, ao corpo são algumas das áreas para as quais os resultados das pesquisas de gênero mais diretamente contribuiram. A epidemia de HIV/Aids selou definitivamente esta parceria entre a sensibilidade de gênero e a prática médica. Não bastava o domínio preciso de recursos técnicos e terapêuticos; era também preciso sensibilidade sociológica para a diversidade dos papéis de gênero. Mulheres e homens se expunham diferentemente à epidemia, 
e um mesmo discurso preventivo nāo era capaz de contemplar suas particularidades. A feminizaçāo da epideruia é um claro indício de como a socialização do feminino é um fator de vulnerabilizaçāo das mulheres em inúmeras sociedades.

Outro tema de grande interesse para os estudos de gênero é a divisāo social do trabalho. É fácil perceber o viés de gênero presente em algumas carreiras médicas: há um grande número de mulheres pediatras e obstetras, ao passo que há poucas neurocirurgiās ou ortopedistas. Descrever este fenömeno é relativamente simples, pois basta olhar para o número de homens e mulheres em cada residência médica referente a essas especializaçōes. $O$ desafio, portanto, é entender o que torna as mulheres mais sensíveis a determinadas carreiras, e os homens a outras. $O$ fato de um número maior de mulheres ou de homens optar por certas especialidades em detrimento de outras nāo deve ser ignorado. Aspectos relacionados à nossa socialização de gênero fundamentam estas escolhas, o que nāo significa que algumas pessoas nāo possam redescrever estas expectativas de gênero, fazendo com que tenhamos mulheres ortopedistas e homens obstetras.

As perspectivas de gênero alteram nossa percepção do que é considerado normal ou tradicional. As escolhas profissionais de homens e mulheres são, em larga medida, fun- damentadas em pressupostos de gênero e, por isso, normalizadas. Argumentos como "uma boa pediatra é uma mulher porque ela é mãe" ou "para ser um bom ortopedista é preciso força" sāo mais resultado de nossas definiçōes do feminino (mulheres como mães) e do masculino (homens como fortes) do que decorrência de análises de competências ou talentos. Temos tanto excelentes pediatras homens quanto competentes mulheres ortopedistas. Mas os pressupostos de gênero relacionados às nossas construçōes do feminino e do masculino funcionam como uma resistência à percepção desses talentos ou mesmo ao incentivo desses talentos ainda na universidade.

É preciso uma revisão do ensino médico a partir das perspectivas de gênero. Perguntas sobre a linguagem utilizada para descrever doenças e disfunçōes, como foi o caso de expressōes comuns da obstetrícia do passado, devem ser revistas a partir de uma sensibilidade de gênero. Uma compreensāo dos papéis de gênero comuns a determinados grupos sociais é um dado decisivo para a eficácia de uma prescrição médica, e há inúmeras pesquisas que demonstram esse dado. Certamente, o incremento da sensibilidade de gênero no ensino da Medicina formará médicos e médicas com maior habilidade para a compreensão do sofrimento humano. 